\title{
Ectopic pregnancy in a previous Caesarean section scar-Case Report
}

\author{
Karl Cutajar, Silvaine Marie Dalli*, Mark Sant and Charles Savona Ventura \\ Mater Dei Hospital, University of Malta, Malta
}

Submission: March 23, 2017 ; Published: April 24, 2017

*Corresponding author: Silvaine Marie Dalli, Mater Dei Hospital, University of Malta, Malta, Email: silvaine.dalli@gmail.com

\begin{abstract}
Objectives: To describe a case report of an ectopic pregnancy in a previous caesarean scar.

Case Report: A 32 year old quintagravida presented with symptomatology and diagnosis of a silent miscarriage. Medical termination with misoprostol was attempted followed by surgical evacuation. During surgery excessive bleeding and a defect in the anterior wall of the uterus was noted. Laparotomy was performed to excise the scar tissue and repair the uterus.
\end{abstract}

Discussion: An embedded gestational sac is quite rare yet its incidence might increase due to the increasing rate of caesarean sections. Diagnosis via various modalities in high risk patients must be performed, including ultrasound and MRI.

Conclusions: When a surgical evacuation is done, care must be taken to identify products of conception embedded in the previous caesarean section scar

\section{Introduction}

Retained products of conception, trauma to the uterus or cervix, poor uterine contractility or cervical pregnancies are all causes of prolonged bleeding after an incomplete miscarriage, yet previous caesarean section scar gestations are most often overlooked or not thought of. The first case of post-abortal haemorrhage caused by a Caesarean section scar implantation was described in 1978 [1]. There have since been a few other solitary cases described. Some have followed formal attempts at surgical terminations of pregnancy following a failed attempt at a medical termination [2]. An increased index of suspicion and early diagnosis may aid in avoiding unwanted circumstances. The present case describes a case of severe haemorrhage during an attempt at surgical evacuation after a failed attempt of medical management of a missed miscarriage.

\section{Case}

The patient, a 32 -year-old gravida 5 para $3^{+1}$ presented with bleeding per vaginam and mild abdominal cramps at 14 weeks of gestation. The patient had had similar episodes at 5 and 10 weeks respectively of this unplanned pregnancy which had settled spontaneously. The patient's obstetric history included three previous caesarean sections with the last one four years previously. She had in the interim had a spontaneous miscarriage requiring surgical evacuation. She had turned down the offer of a tubal sterilization after her last Caesarean section. On clinical examination, vaginal bleeding was moderate while the cervical os was closed. An ultrasound scan showed a foetus with a CrownRump Length of $3.5 \mathrm{~cm}$ with absence of foetal heart motion or foetal movements. There was also a clot of about $3.8 \times 1.72 \mathrm{~cm}$ size low in the uterine cavity. In view of the closed cervix, an initial decision for medical management was taken. $800 \mathrm{mcg}$ of misoprostol were inserted in the posterior fornix. A few hours later, products of conception (POC) were noted in the cervical os on examination. These were removed, but vaginal bleeding continued to be moderate to severe, despite a bolus dose of syntometrin injection and a syntocinon infusion. A formal suction curette exploration of the uterine cavity was performed with the removal of further placental products. In spite of this the severe uterine bleeding continued. Digital exploration of the uterine cavity suggested a defect at the site of the old uterine scar, and a laparotomy was performed in view of the previous obstetric history and the examination findings.

At laparotomy, POC were noted to be embedded in the previous caesarean section scars extending throughout the thickness of the uterine wall. The uterine scar was excised together with the remaining POC, and the uterus was sutured 
in two layers to control the bleeding. Histology confirmed normal trophoblastic tissue. The post-operative period was uneventful. The patient was later advised to strongly consider effective contraception, after which she opted for insertion of a levonorgestrel containing intrauterine device.

\section{Discussion}

A gestational sac in a previous caesarean section scar is the rarest form of ectopic pregnancy and its diagnosis requires a very high index of suspicion since its symptoms could easily be due to a miscarriage $[1,3-5]$. Since the first case reported was by Larsen et al. [1], there has been a slow increase in incidence in the past years possibly due to the progressive overall increase in caesarean section rates $[3,4,6]$. Presently, its incidence ranges from 1:1800 to $1: 12216$ of normal pregnancies with the majority having had only one previous caesarean section [7].

A diagnosis of scar gestation needs to be definitively ruled out in women with a history of caesarean section and continuous haemorrhage during surgical evacuation of POC [8-10]. A preintervention diagnosis may be suggested by a trans-vaginal ultrasound examination [11,12], which could possibly show a gestational sac in the lower anterior uterine wall in the region of the previous caesarean section scar with the rest of the uterine cavity being empty $[4,9]$. Increased peri-trophoblastic activity on doppler or absence of a healthy myometrium between the bladder and the sac might be early signs with a previous history of caesarean section [4]. MRI diagnosis was also suggested by Yves et al in patients with an inconclusive trans-vaginal ultrasound scan [13].

Medical termination of the pregnancy using misoprostol in such a situation may result in partial evacuation of the uterus followed by continuing post-abortion bleeding. This would require urgent surgery to control the haemorrhage. In this case, resection of the scar edges with the infiltrating POC with resuturing was undertaken since the patient was not consented for a hysterectomy. Pre-intervention diagnosis of a surgical scar pregnancy would enable an attempt at medical termination with systemic or localized methotrexate. This intervention has shown mixed results with a percentage still requiring surgical evacuation or laparoscopic/laparotomy removal of the uterine scar and POC $[3,5,6,14]$. Such form of termination is obviously unsuitable in advanced gestations, yet it may be considered as a suitable first line treatment in uncomplicated, stable cases who prefer conservation of fertility [3]. Most of the literature recommends against "blind" surgical vaginal evacuation of POC in diagnosed uterine scar gestations unless done under direct vision $[15,16]$. However, some units have successfully used ultrasound -guided suction curettage, with those who needed further haemostasis receiving a Shirodkar stitch [17]. Operative hysteroscopic removal might be an alternative choice [15]. Alternatively, laparoscopic removal of the POC, the sacculus and scar tissue can be carried out ensuring proper obliteration of the wound. This method will allow for safe removal of all the tissue and should only be undertaken by experienced laparoscopic surgeons, especially since the latest that this was done was in an 11 week gestation $[18,19]$.

Serial monitoring with serum b-HCG levels should also be carried out to ensure against persistence of active trophoblastic tissue. Because of the risks of a recurrence, tubal ligation during the procedure should also be considered if the patient has a complete family and if prior proper consent obtained.

\section{Conclusion}

Although rare, obstetric patients with previous caesarean sections are at risk of having an ectopic pregnancy in the uterine scar often complicated by abnormal infiltration of the trophoblastic tissue. This complication needs to be considered and ruled out before any attempts at medical or surgical termination of pregnancy or in managing a spontaneous missed abortion. The use of trans-vaginal scanning and proper interpretation can aid such diagnosis and avoid unwanted complications whilst conserving future fertility. Blind vaginal surgical evacuation needs to be avoided with the laparoscopic or operative hysteroscopic approach being the preferred means of manual removal of the products of conception and possible scar tissue.

\section{References}

1. Larsen J (1978) Pregnancy in a uterine scar sacculus -an unusual cause of postabortal haemorrhage. A case report. S Afr Med J 53: 142-143.

2. Shojai R, Roblin P, Boubli L (2012) Failed early medical abortion: Beware of the uterine scar!-Case report. The European. Journal of Contraception and Reproductive Health Care 17(3): 237-239.

3. Hong S, Lau M, Yam P (2011) Ectopic pregnancy in previous Caesarean section scar. Singapore Med J 52(6): e115-e117.

4. Tan G, Chong Y, Biswas A (2005) Caesarean Scar Pregnancy: A Diagnosis to Consider Carefully in Patients with Risk Factors. Ann Acad Med Singapore 34: 216-219.

5. Godin P, Bassil S, Donnez J (1997) An ectopic pregnancy developing in a previous caesarean section scar. Fertil Steril 67(2): 398-400.

6. Mini C, Rabiyabi V (2008) Case report: Caesarean scar ectopic pregnancy. Calicut Medical Journal 6(4): e7.

7. Rotas M, Haberman S, Levgur M (2006) Cesarean scar ectopic pregnancies: etiology, diagnosis, and management. Obstet Gynecol 107(6): 1373-1381.

8. Chazotte C, Coher W (1990) Catastrophic complications of a previous cesarean section. Am J Obstet Gynecol 163(3): 738-742.

9. Einenkel J, Stumpp P, Kösling S, Horn LC, Höckel M (2005) A misdiagnosed case of caesarean scar pregnancy. Arch Gynecol Obstet 271(2): 178-181.

10. Nonanka M, Toyoki H, Imai A (2006) Cesarean section scar pregnancy may be the cause of serious hemorrhage after first-trimester abortion by dilation and curettage. Int J Gynaecol Obstet 95(1): 50-51.

11. Rotas M, Shoshana H, Levgur M (2006) Cesarean scar ectopic pregnancies: etiology, diagnosis and management. Obstet Gynecol 107(6): 1373-1381.

12. Jurkovic D, Knez J, Appiah A, Farahani L, Mavrelos D, et al. (2016) Surgical treatment of Cesarean scar ectopic pregnancy: efficacy and 
safety of ultrasound-guided suction curettage. Ultrasound in Obstetrics and Gynaecology 47(4): 511-517.

13. Jacquemyn Y, Kerremans M, Op de Beeck B, Colpaert C (2012) Reminder of important clinical lesson: Caesarean scar pregnancy. BMJ Case Reports.

14. Fylstra D (2002) Ectopic pregnancy within a caesarean scar: a review. Obstet Gynecol Surv 57(8): 537-543.

15. Deans R, Abbott J (2010) Hysteroscopic management of cesarean scar ectopic pregnancy. Fertil Steril 93(6): 1735-1740.

16. Wang CJ, Yuen LT, Chao AS, Lee CL, Yen CF, et al. (2005) Caesarean scar pregnancy successfully treated by operative hysteroscopy and suction curettage. Br J Obstet Gynecol 112(6): 839-840.
17. Jurkovic D, Hillaby K, Woelfer B, Lawrence A, Salim R, et al. (2003) First trimester diagnosis and management of pregnancies implanted into the lower uterine segment cesarean section scar. Ultrasound Obstet Gynecol 21(3): 220-207.

18. Wang Y, Su T, Chen H (2006) Operative laparoscopy for unruptured ectopic pregnancy in a cesarean scar. Br J Obstet Gynecol 113(9): 1035 -1038 .

19. Fuchs N, Manoucheri E, Verbaan M, Einarsson J (2014) Laparoscopic management of extrauterine pregnancy in caesarean section scar: description of a surgical technique and review of the literature. BJOG 122(1): $137-140$

\section{Your next submission with Juniper Publishers} will reach you the below assets

- Quality Editorial service

- Swift Peer Review

- Reprints availability

- E-prints Service

- Manuscript Podcast for convenient understanding

- Global attainment for your research

- Manuscript accessibility in different formats

( Pdf, E-pub, Full Text, Audio)

- Unceasing customer service

Track the below URL for one-step submission https://juniperpublishers.com/online-submission.php 